\title{
MDR1 C3435T and C1236T Polymorphisms: Association with High-risk Childhood Acute Lymphoblastic Leukemia
}

\author{
Wanida Pongstaporn ${ }^{1 *}$, Samart Pakakasama ${ }^{2}$, Panee Chaksangchaichote ${ }^{3}$, Tanett \\ Pongtheerat $^{4}$, Suradej Hongeng ${ }^{2}$, Songsak Permitr ${ }^{3}$
}

\begin{abstract}
Background: MDR1, one of the most important drug-transporter genes, encodes P-glycoprotein (P-gp)-a transporter involved in protecting against xenobiotics and multi-drug resistance. The significance of the genetic background in childhood acute lymphoblastic leukemia (ALL) is not well understood. Materials and Methods: To evaluate whether C3435T and C1236T MDR1 polymorphisms are associated with the occurrence and outcome of ALL, 208 children with ALL (median age $5.0 \mathrm{yr}$ ) and 101 healthy Thai children were studied by polymerase chain reaction-restriction fragment-length polymorphism (PCR-RFLP) assay. Results: C3435T and C1236T $M D R 1$ polymorphism are significantly associated with the high-risk group $(\mathrm{OR}=2.6,95 \% \mathrm{CI}=1.164-5.808 ; \mathrm{P}$ $=0.028$ and $\mathrm{OR}=2.231,95 \% \mathrm{CI}=1.068-4.659 ; \mathrm{p}=0.047$, respectively $)$, indicating that both may be candidates for molecular markers in the high-risk group of ALL.
\end{abstract}

Keywords: Acute lymphoblastic leukemia - MDRI polymorphism - high-risk group - Thailand

Asian Pac J Cancer Prev, 16 (7), 2839-2843

\section{Introduction}

Acute lymphoblastic leukemia (ALL) is the most common childhood malignancy worldwide. Thanks to improvements in the treatment of childhood ALL, 30\% of cases are cured. However, $80 \%$ of patients remain in the remission stage for 10 years, and $20 \%$ of children suffer recurrence, making the final cure rate $25-40 \%$ (Claus et al., 2012). The effects of various prognostic factors on the clinical outcome of ALL have been investigated with improvements in treatment, however, increased use of more intensive therapy has led to the emergence of new adverse sequelae, especially in high-risk cases (Pui et al., 2004).

Inherited susceptibility and specific environmental exposure are supposed to play a major role in the pathogenesis of ALL (Martin et al., 2007). Moreover, drug effects may be different in the presence of alterations of genes involved in drug metabolism. Functional polymorphism of genes that encode proteins important for the metabolism of anti-cancer drugs (such as the thiopurine methyl transferase gene, or the reduced folate carrier gene) influence the outcome of chemotherapy in ALL (McLeod et al., 2000; Lavedrier et al., 20002). Drug transporters are the major proteins crucial for drug metabolism, and the MDRl gene, encoding for $\mathrm{P}$-glycoprotein ( $\mathrm{P}-\mathrm{gp})$, is the most important of these drug transporters. P-gp is a
$170 \mathrm{kd}$ member of the adenosine triphosphate-binding cassette (ABC) superfamily of membrane transporters (Kerb, 2006). The most important physiologic role of P-gp is in protecting the organism against toxic xenobiotics associated with mutagenic activity. MDR is a major challenge to effective chemotherapeutic intervention against cancer. Recently, the mechanism underlying this phenomenon have been reviewed thoroughly. (Ullah, 2008). Likewise, P-glycoprotein expression in tumor cells is associated with the multi-drug resistance phenotype in some hematological malignancies (Jamroziak and Rodak, 2004).

Several studies on the effects of C1236T (rs128503), C3435T (rs1045642), and G2677T/A (rs2032582) SNPs on MDRl expression and function in tissues have been conducted in different populations (Kim et al., 2001; Taheri et al., 2010; Samanian et al., 2011). In addition, several lines of evidence have shown a significant correlation between $\mathrm{C} 3435 \mathrm{~T}$ polymorphism and risk factors or clinical outcomes of human cancer, such as hematologic malignancy (Sheng et al., 2012), breast and renal cancers (Wang et al., 2012), lung cancer (Wei et al., 2012), colorectal cancer (He et al., 2013), thyroid cancer (Ozmedir et al., 2013). Moreover, in Chinese non small lung cancer patients, it was shown that $\mathrm{CC}$ genotype of C3435T polymorphism is significantly associated with response rate of platinum-based chemotherapy (Yan et

${ }^{1}$ Pathobiology Unit, ${ }^{4}$ Biochemistry Unit, Department of Biomedical Science, Faculty of Science, Rangsit University, Pathumthani, ${ }^{2}$ Department of Pediatrics, Ramathibodi Hospital, Faculty of Medicine, ${ }^{3}$ Department of Molecular Tropical Medicine and Genetics, Faculty of Tropical Medicine, Mahidol University, Bangkok, Thailand *For correspondence: wanida.po@rsu.ac.th 
al., 2011). However, some evidence have shown there is no significant correlation between C3435T polymorphism and risk factors of cancer, such as gastric cancer (Wu et al., 2014) and chronic lymphocytic leukemia (Dong et al., 2011). The conflict results may be due to ethnic sampling and number of cases.

In this study, the association between C3435T and C1236T polymorphisms of the MDRl gene and the clinical characteristics of ALL were observed. The results may help develop new candidate molecular markers for ALL.

\section{Materials and Methods}

\section{Specimens}

In this retrospective study, 207 ALL patients (86 females and 121 males) with a median age of 5 years (range 1-14 years), and 101 healthy Thai children (45 females and 56 males) with a median age of 12 years (range 2-13 years), were assessed by the Department of Pediatrics, Faculty of Medicine, Ramathibodi Hospital, Mahidol University. This study was approved by the Ethics Committee, Faculty of Medicine, Ramathibodi Hospital, Mahidol University. Patients were classified by risk-based assignment protocol (Smith et al., 1996). In general, risk was defined by initial white blood cell count, age at diagnosis, French American British morphology, and lymphomatous disease status. Moreover, clinical data including age at diagnosis, sex, immunophenotype, and chromosome abnormalities were studied retrospectively.

\section{DNA isolation}

Genomic DNA was isolated from $3 \mathrm{ml}$ fresh EDTA blood by proteinase $\mathrm{K}$ digestion and salting out method (Miler et al., 1988) with some modification. Red blood cells were briefly lysed with $100 \%$ Triton X-100, and the white blood cell pellets were incubated in lysis buffer (10 mM Tris HCl, pH8.0, 400 mM NaCl, 2mM EDTA), 200 $\mu \mathrm{L}$ of $10 \% \mathrm{SDS}$ and $10 \mathrm{mg} / \mathrm{ml}$ proteinase $\mathrm{K}$ at $60^{\circ} \mathrm{C}$ for 3 hours. The solution was mixed with $6 \mathrm{M} \mathrm{NaCl}$, then shaken and centrifuged at $10,000 \mathrm{~g}$ at $4^{\circ} \mathrm{C}$ for $10 \mathrm{~min}$. DNA was precipitated by absolute ethanol and washed three times with $70 \%$ cold ethanol. The DNA pellet was dissolved in TE buffer and kept at $-20^{\circ} \mathrm{C}$ prior to use.

\section{Genotyping of MDR1 C3435T polymorphism}

Genotyping of MDR1 C3435T polymorphism of ALL patients and controls was performed by PCR-RFLP assay, as described previously (Jamroziak et al., 2004). The C3435T polymorphism of MDR1 was detected after PCR amplification using forward primer 5' TTG ATG GCAAAG AAA TAAAGC 3' and reverse primer 5' CTT ACA TTA GGC AGT GAC TCG 3'. DNA amplification was carried out in $50 \mu \mathrm{L}$ reaction mixture containing PCR buffer (10mM Tris- $\mathrm{HCl}$, pH $9.050 \mathrm{mM} \mathrm{KCl}, 1.5 \mathrm{mM}$ $\mathrm{MgCl} 2) 200 \mu \mathrm{M}$ of each dNTP, 1 unit of Taq DNA polymerase (Pharmacia, Biotech, USA), $20 \mu \mathrm{M}$ of each primer and 100ng of genomic DNA. Thermal cycling was performed in a Gene Amp PCR System 9700 (Perkin Elmer, USA) for 30 cycles; each consisting of denaturation at $94^{\circ} \mathrm{C}$ for $90 \mathrm{~s}$, annealing at $56^{\circ} \mathrm{C}$ for $60 \mathrm{~s}$ and extension at $72^{\circ} \mathrm{C}$ for $90 \mathrm{~s}$. PCR amplicons were digested by MboI at $37^{\circ} \mathrm{C}$ for 16 hours, electrophoresed on $2 \%$ agarose gel, stained with ethidium bromide, and visualized under UV light. The digested product showed 3 different patterns; wild type homozygote $(\mathrm{C} / \mathrm{C})$, demonstrating 130 and 76 bp fragments, polymorphic homozygote (T/T) with 206 bp fragments and C/T heterozygote with 206, 130, and $76 \mathrm{bp}$ fragments.

\section{Genotyping of MDR1 C1236T polymorphism}

Genotyping of MDR1 C1236T polymorphism of ALL patients and controls was performed by PCRRFLP assay with modification (Ryu et al., 2006). The C1236T polymorphism of MDRl was detected after PCR amplification using forward primer 5' TGT GTC TGT GAA TTG CCT TGA 3' and reverse primer 5' ATC TCA CCA TCC CCT CTG TG 3'. DNA amplification was carried out in $50 \mu \mathrm{L}$ of reaction mixture containing PCR buffer (10mM Tris- $\mathrm{HCl}, \mathrm{pH} 9.050 \mathrm{mM} \mathrm{KCl}, 1.5 \mathrm{mM}$ $\mathrm{MgCl} 2), 200 \mu \mathrm{M}$ of each dNTP, 1 unit of Taq DNA polymerase (Pharmacia, Biotech, USA), 20 $\mu \mathrm{M}$ of each primer and 100ng of genomic DNA. Thermal cycling was performed in a Gene Amp PCR System 9700 for 40 cycles; each consisted of denaturation at $94^{\circ} \mathrm{C}$ for $60 \mathrm{~s}$, annealing at $56^{\circ} \mathrm{C}$ for $60 \mathrm{~s}$, extension at $72^{\circ} \mathrm{C}$ for $60 \mathrm{~s}$, and final extension $72^{\circ} \mathrm{C}$ for $5 \mathrm{~min}$. PCR amplicons were digested by HaeIII at $37^{\circ} \mathrm{C}$ for 16 hours, electrophoresed on $4 \%$ NuSieve Agarose SFRTM, stained with ethidium bromide, and visualized under UV light. The digested product showed 3 different patterns; wild type homozygote(C/C), demonstrating 93 and $87 \mathrm{bp}$ fragments, polymorphic homozygote (T/T) showing 87,58 , and 35 bp fragments, and $\mathrm{C} / \mathrm{T}$ heterozygote, showing $93,87,58$, and 35 bp fragments.

\section{Statistical analysis}

Differences in genotypes between cases and controls were determined by Chi-square test. Crude odds ratios (OR) and 95\% confidence intervals (CI) were also calculated. The association between C3435T and C1236T polymorphism of $M D R 1$ and prognostic factors for ALL, e.g. age at diagnosis, sex, gender, immunophenotype and risk group, were calculated by binary logistic regression analysis using the SPSS version 11.5 program (SPSS Inc., Chicago, USA).

\section{Results}

The association between C3435T and C1236T of MDRI polymorphisms and ALL susceptibility

The allele frequencies for C3435T and C1236T of MDRl polymorphisms were determined in the childhood ALL and control groups. The allele frequency of C3435T $M D R 1$ polymorphism in the controls was 0.43 , compared with 0.41 in ALL patients, and the allele frequency of C1236T MDRl polymorphism in the controls was 0.43 , compared with 0.46 in ALL patients. All allele frequencies were in agreement with the Hardy-Weinberg equilibrium. There was no statistically significant correlation between the allele frequency of either C3435T MDR1 polymorphism or C1236T MDR1 polymorphism and ALL susceptibility $(\mathrm{OR}=0.811,95 \% \mathrm{CI}=0.483-1.363, \mathrm{p}=0.510)$ 
and $(\mathrm{OR}=1.3,95 \% \mathrm{CI}=0.7417-2.4680, \mathrm{p}=0.6898)$, 1 1 Polymorphisms and Childhood Acute Lymphoblastic Leukemia

respectively. (Table1).

The association between C3435T and C1236T of MDR1 polymorphisms and high risk $A L L$

With modern chemotherapy, ALL patients can be classified as high-risk (white blood cell count $>50,000$ cell/ $\mu$ l, age $>10$ years, or with T-cell immunophenotype),

Table 1. Distribution of C3435T and C1236T MDR1 Genotypes in ALL, Compared with Controls

\begin{tabular}{|c|c|c|c|c|}
\hline Genotypes & ALL $(\%)$ & Controls $(\%)$ & OR $(95 \% \mathrm{CI}) \quad \mathrm{P}$ & P-value \\
\hline \multicolumn{5}{|c|}{ MDR1 (exon26/3435) } \\
\hline $\mathrm{C} / \mathrm{C}$ & $69(33.17)$ & $29(28.71)$ & 1.00 (Reference) & \\
\hline $\mathrm{C} / \mathrm{T}$ & $106(50.96)$ & $58(57.43)$ & $0.77(0.45-1.32)$ & 0.41 \\
\hline$T / T$ & $33(15.87)$ & $14(13.86)$ & $0.99(0.46-2.12)$ & 0.86 \\
\hline $\mathrm{C} / \mathrm{T}+\mathrm{T} / \mathrm{T} 1$ & $139(66.83)$ & $72(71.28)$ & $0.81(0.48-1.36)$ & 0.51 \\
\hline \multicolumn{5}{|c|}{ Allele frequency } \\
\hline \multirow[t]{2}{*}{ C3435 } & 0.59 & 0.57 & & \\
\hline & 0.41 & 0.43 & & \\
\hline \multicolumn{5}{|c|}{ MDR1 (exon12/1236) } \\
\hline $\mathrm{C} / \mathrm{C}$ & $34(17.43)$ & $22(22.22)$ & 1.00 (Reference) & \\
\hline $\mathrm{C} / \mathrm{T}$ & $141(72.31)$ & $68(68.69)$ & $1.34(0.73-2.47)$ & 0.43 \\
\hline $\mathrm{T} / \mathrm{T}$ & $20(10.26)$ & $9 \quad(9.09)$ & $1.44(0.55-3.72)$ & 0.61 \\
\hline $\mathrm{C} / \mathrm{T}+\mathrm{T} / \mathrm{T}$ & $161(82.56)$ & $71(71.72)$ & $1.35(0.74-2.47)$ & 0.69 \\
\hline \multicolumn{5}{|c|}{ Allele frequency } \\
\hline C1236 & 0.54 & 0.57 & & \\
\hline T1236 & 0.46 & 0.43 & & \\
\hline
\end{tabular}

Table 2. Demographic Data of ALL Patients of C3435T MDR1 Genotypes

\begin{tabular}{lrccc}
\hline \multirow{2}{*}{$\begin{array}{l}\text { Demographic } \\
\text { data }\end{array}$} & Total patients & \multicolumn{3}{c}{ MDR1 } \\
\cline { 4 - 5 } Sex & $\mathrm{n}(\%)$ & $\mathrm{CC}$ & $\mathrm{C} / \mathrm{T}$ or T/T & $\mathrm{p}$ value \\
$\quad$ Male & 121 & $36(29.75)$ & $85(70.25)$ & 0.253 \\
Female & 86 & $33(38.37)$ & $53(61.63)$ & \\
Age at diagnosis & & & & \\
1-10 years & 136 & $49(36.03)$ & $87(63.97)$ & 0.149 \\
$>10$ years & 51 & $12(23.53)$ & $39(76.47)$ & \\
Risk classification & & & & \\
$\quad$ Standard risk & 136 & $51(37.5)$ & $85(62.5)$ & $0.028^{*}$ \\
$\quad$ High Risk & 48 & $9(18.75)$ & $39(81.25)$ & \\
Immunophenotype & & & & \\
$\quad$ Non T cell & 168 & $55(32.74)$ & $113(67.26)$ & 0.306 \\
T cell & 21 & $4(19.05)$ & $17(80.95)$ & \\
\hline
\end{tabular}

Table 3. Demographic Data of ALL Patients of C1236T MDR1 Genotypes

\begin{tabular}{|c|c|c|c|c|}
\hline \multirow{2}{*}{$\begin{array}{l}\text { Demographic } \\
\text { data }\end{array}$} & \multicolumn{2}{|c|}{ Total patients } & \multicolumn{2}{|l|}{ MDR1 } \\
\hline & $\mathrm{n}(\%)$ & $\overline{\mathrm{CC}}$ & $\mathrm{C} / \mathrm{T}$ or $\mathrm{T} / \mathrm{T}$ & $\overline{p \text { value }}$ \\
\hline \multicolumn{5}{|l|}{ Sex } \\
\hline Male & 117 & $43(36.75)$ & $74(63.25)$ & \multirow[t]{2}{*}{0.127} \\
\hline Female & 80 & $39(48.75)$ & $41(51.25)$ & \\
\hline \multicolumn{5}{|c|}{ Age at diagnosis } \\
\hline $1-10$ years & 136 & $59(43.38)$ & $77(56.62)$ & \multirow[t]{2}{*}{0.767} \\
\hline$>10$ years & 51 & $21(41.18)$ & $30(58.82)$ & \\
\hline \multicolumn{5}{|c|}{ Risk classification } \\
\hline Standard risk & 136 & $58(42.65)$ & $78(57.35)$ & \multirow[t]{2}{*}{$0.047 *$} \\
\hline High Risk & 48 & $12(25)$ & $36(75)$ & \\
\hline \multicolumn{5}{|c|}{ Immunophenotype } \\
\hline Non $\mathrm{T}$ cell & 157 & $66(42.04)$ & $91(57.96)$ & \multirow[t]{2}{*}{0.784} \\
\hline $\mathrm{T}$ cell & 22 & $8(36.36)$ & $14(63.64)$ & \\
\hline
\end{tabular}

and low-risk (white blood cell count $<50,000 / \mu$ l, or age $<10$ years). This study indicates that the high-risk ALL group was significantly associated with $\mathrm{C} 3435 \mathrm{~T}(\mathrm{OR}=$ 2.6, 95\% CI =1.164-5.808; $\mathrm{p}=0.028$ ) (Table 2) and C1236T MDR 1 polymorphism $(\mathrm{p}=0.028, \mathrm{OR}=2.231,95 \% \mathrm{CI}$ =1.068-4.659; $\mathrm{p}=0.047$ ) (Table3).

Clinical characteristic of high risk ALL

The correlation between the clinical characteristics of the ALL patients in the high-risk group with the C1236T

Table 4. Clinical Data of ALL in the High Risk Group and MDR1 Gene Polymorphism $(n=48)$

\begin{tabular}{|c|c|c|c|c|c|}
\hline No. & $\begin{array}{c}\text { Age }>10 \\
\text { years }\end{array}$ & $\begin{array}{c}\text { WBC } \\
>50,000 / \mathrm{mL}\end{array}$ & $\begin{array}{l}\text { Immuno- } \\
\text { phenotype }\end{array}$ & C3435T & C1236T \\
\hline 1 & yes & yes & Pre-B & $\mathrm{C} / \mathrm{T}$ & $\mathrm{C} / \mathrm{C}$ \\
\hline 2 & No & No & T-cell & $\mathrm{C} / \mathrm{C}$ & $\mathrm{C} / \mathrm{T}$ \\
\hline 3 & No & No & T-cell & $\mathrm{C} / \mathrm{T}$ & $\mathrm{C} / \mathrm{T}$ \\
\hline 4 & yes & yes & Early-PreB & $\mathrm{C} / \mathrm{T}$ & $\mathrm{C} / \mathrm{T}$ \\
\hline 5 & yes & yes & Pre-B & $\mathrm{C} / \mathrm{T}$ & $\mathrm{C} / \mathrm{T}$ \\
\hline $6^{*}$ & yes & No & Pre-B & $\mathrm{C} / \mathrm{T}$ & $\mathrm{C} / \mathrm{T}$ \\
\hline 7 & yes & yes & Pre-B & $\mathrm{C} / \mathrm{T}$ & $\mathrm{C} / \mathrm{C}$ \\
\hline 8 & yes & No & Pre-B & $\mathrm{T} / \mathrm{T}$ & $\mathrm{C} / \mathrm{T}$ \\
\hline 9 & yes & yes & T-cell & $\mathrm{C} / \mathrm{T}$ & $\mathrm{C} / \mathrm{T}$ \\
\hline 10 & yes & No & Pre-B & $\mathrm{T} / \mathrm{T}$ & $\mathrm{C} / \mathrm{T}$ \\
\hline 11 & yes & No & Pre-B & $\mathrm{C} / \mathrm{T}$ & $\mathrm{C} / \mathrm{T}$ \\
\hline 12 & yes & No & Pre-B & $\mathrm{C} / \mathrm{T}$ & $\mathrm{C} / \mathrm{T}$ \\
\hline 13 & yes & No & Pre-B & $\mathrm{T} / \mathrm{T}$ & $\mathrm{C} / \mathrm{T}$ \\
\hline 14 & No & yes & T-cell & $\mathrm{C} / \mathrm{T}$ & $\mathrm{C} / \mathrm{C}$ \\
\hline $15^{*}$ & yes & No & Pre-B & $\mathrm{C} / \mathrm{C}$ & $\mathrm{C} / \mathrm{T}$ \\
\hline 16 & yes & yes & Pre-B & $\mathrm{C} / \mathrm{T}$ & $\mathrm{C} / \mathrm{C}$ \\
\hline 17 & No & No & T-cell & $\mathrm{C} / \mathrm{T}$ & $\mathrm{C} / \mathrm{T}$ \\
\hline 18 & No & yes & T-cell & $\mathrm{C} / \mathrm{T}$ & $\mathrm{C} / \mathrm{T}$ \\
\hline 19 & No & yes & Pre-B & $\mathrm{C} / \mathrm{T}$ & $\mathrm{C} / \mathrm{C}$ \\
\hline 20 & No & yes & T-cell & $\mathrm{C} / \mathrm{T}$ & $\mathrm{C} / \mathrm{C}$ \\
\hline 21 & yes & yes & T-cell & $\mathrm{C} / \mathrm{T}$ & $\mathrm{C} / \mathrm{T}$ \\
\hline 22 & yes & yes & Pre-B & $\mathrm{C} / \mathrm{T}$ & $\mathrm{C} / \mathrm{C}$ \\
\hline 23 & No & yes & Pre-B & $\mathrm{T} / \mathrm{T}$ & $\mathrm{C} / \mathrm{C}$ \\
\hline $24 *$ & yes & No & Pre-B & $\mathrm{C} / \mathrm{T}$ & $\mathrm{C} / \mathrm{T}$ \\
\hline 25 & No & yes & Pre-B & $\mathrm{C} / \mathrm{T}$ & $\mathrm{C} / \mathrm{T}$ \\
\hline 26 & yes & No & T-cell & $\mathrm{C} / \mathrm{T}$ & $\mathrm{C} / \mathrm{T}$ \\
\hline 27 & yes & yes & T-cell & $\mathrm{C} / \mathrm{T}$ & $\mathrm{C} / \mathrm{T}$ \\
\hline 28 & yes & No & T-cell & $\mathrm{T} / \mathrm{T}$ & $\mathrm{C} / \mathrm{C}$ \\
\hline 29 & yes & yes & B-cell & $\mathrm{C} / \mathrm{T}$ & $\mathrm{C} / \mathrm{T}$ \\
\hline 30 & yes & No & Pre-B & $\mathrm{C} / \mathrm{T}$ & $\mathrm{C} / \mathrm{T}$ \\
\hline 31 & yes & No & T-cell & $\mathrm{C} / \mathrm{T}$ & $\mathrm{C} / \mathrm{T}$ \\
\hline 32 & yes & No & Pre-B & $\mathrm{C} / \mathrm{C}$ & $\mathrm{C} / \mathrm{C}$ \\
\hline 33 & yes & No & Pre-B & $\mathrm{C} / \mathrm{T}$ & $\mathrm{C} / \mathrm{T}$ \\
\hline 34 & yes & No & T-cell & $\mathrm{T} / \mathrm{T}$ & $\mathrm{C} / \mathrm{T}$ \\
\hline 35 & No & No & Early-PreB & $\mathrm{C} / \mathrm{C}$ & $\mathrm{C} / \mathrm{T}$ \\
\hline 36 & No & No & Early-PreB & $\mathrm{C} / \mathrm{C}$ & $\mathrm{C} / \mathrm{T}$ \\
\hline 37 & yes & yes & T-cell & $\mathrm{C} / \mathrm{T}$ & $\mathrm{C} / \mathrm{T}$ \\
\hline 38 & yes & No & Early-PreB & $\mathrm{C} / \mathrm{C}$ & $\mathrm{C} / \mathrm{C}$ \\
\hline 39 & yes & No & Mixed & $\mathrm{C} / \mathrm{T}$ & $\mathrm{C} / \mathrm{C}$ \\
\hline 40 & yes & No & Early-PreB & $\mathrm{T} / \mathrm{T}$ & $\mathrm{C} / \mathrm{T}$ \\
\hline $41 *$ & No & No & Early-PreB & $\mathrm{C} / \mathrm{T}$ & $\mathrm{T} / \mathrm{T}$ \\
\hline $42 *$ & No & No & Pre-B & $\mathrm{C} / \mathrm{T}$ & $\mathrm{C} / \mathrm{T}$ \\
\hline $43^{*}$ & No & No & B-cell & $\mathrm{T} / \mathrm{T}$ & $\mathrm{T} / \mathrm{T}$ \\
\hline 44 & No & No & T-cell & $\mathrm{T} / \mathrm{T}$ & $\mathrm{C} / \mathrm{T}$ \\
\hline 45 & No & No & Early-PreB & $\mathrm{C} / \mathrm{C}$ & $\mathrm{C} / \mathrm{C}$ \\
\hline $46^{*}$ & No & No & Pre-B & $\mathrm{C} / \mathrm{C}$ & $\mathrm{C} / \mathrm{T}$ \\
\hline $47 *$ & yes & yes & Early-PreB & $\mathrm{C} / \mathrm{C}$ & $\mathrm{C} / \mathrm{T}$ \\
\hline $48^{*}$ & No & No & Pre-B & $\mathrm{C} / \mathrm{T}$ & $\mathrm{T} / \mathrm{T}$ \\
\hline
\end{tabular}

*No. 6,15,24,41 and 42 were relapse cases; No. 43 and 48 shows $\mathrm{t}(4 ; 11)$; No. 46 and 47 shows $t(9 ; 22)$ 
Wanida Pongstaporn et al

and C3435T MDR1 gene polymorphisms can be seen in Table 4. It should be noted that 15 of 22 cases of T-cell ALL were high-risk cases. Among these, 14 of 15 (93\%) had C3435T MDRl gene polymorphisms, while 12 of 15 (80\%) harbored C1236T MDRl gene polymorphisms. Notably, 5 of $15(33 \%)$ of the high-risk group were relapse cases (4 cases of Pre-B and one case of Early-pre-B ALL), and exhibited C1236T MDRl gene polymorphism, whereas 3 of the 4 relapse cases exhibited C3435T MDR I gene polymorphism.

Abnormal cytogenetics was found in 4 cases $(27 \%)$ from the high-risk group. Two cases had a $\mathrm{t}(4 ; 11)$ (q21;q23), which is MLL-AF4 fusion, indicating poor prognosis, and carried $\mathrm{C} 3435 \mathrm{~T}$ and $\mathrm{C} 1236 \mathrm{~T} \mathrm{MDRI}$ gene polymorphisms. The other two cases had $\mathrm{t}(9 ; 22)$ (q34;q11), which is BCR-ABL fusion, which also implies poor prognosis, and showed only C1236T MDRl gene polymorphism.

\section{Discussion}

The multi-drug resistance $1(M D R 1$ or ABCB1) gene encodes a $170-\mathrm{kDa}$ membrane transport protein called P-glycoprotein, which acts as an ATP-dependent exporter of xenobiotics from cells and as an efflux transporter conferring resistance to a variety of natural cytotoxic drugs (Borst and Elferink 2002; Ambudkar et al., 2003). It has been suggested that alteration of the cellular defense mechanism mediated by P-gp is closely associated with the development of various cancers, including breast cancer (Wang et al., 2012), colorectal carcinoma (He et al., 2013; Kurzawski et al., 2005), and ALL (Jamroziak and Rodak, 2004; Sheng et al., 2012). Over the past four decades, the treatment of ALL among children has improved dramatically. Despite this success, drug resistance, and treatment failure due to treatment-related toxicity, still occur in about $20 \%$ of patients. A major problem of cytotoxic drug treatment is intrinsic or acquired drug resistance. One potential mechanism of drug resistance is mediated through the expression of the P-gp efflux pump, enabling ALL blasts to decrease intracellular toxic drug levels and thereby lower rates of apoptosis (Hoffmeyer et al., 2000).

Multi-drug resistance (MDR) remains an important challenge during the treatment of acute leukemia. The P-gp function is attributable to the presence of variant MDRl genotypes among ALL patients. These polymorphisms could not only influence the sensitivity or resistance of the leukemic blast, but could also impact therapy outcome by altered drug clearance. It has been reported that genetic polymorphisms of the MDRl gene may affect the expression and function of the P-gp efflux pump in healthy volunteers (Hitzl et al., 2001 ; Nakamura et al., 2002). At least 105 variants have been discovered in the MDRl gene to date. The majority of these SNPs were either intronic or noncoding SNPs, and as such do not change P-gp amino acid composition. Recently, it was demonstrated that the novel $4125 \mathrm{~A}>\mathrm{C}$ polymorphism of $M D R 1$ is associated with susceptibility to hepatocellular carcinoma in Chinese population (Ren et al., 2012) but there still not known the role of this novel polymorphism.
However, the first MDR1 SNP reported to be associated with an alteration of $\mathrm{P}$-gp transport function was the silent mutation $3435 \mathrm{C} \rightarrow \mathrm{T}$ in exon 26 (Komar, 2007). Studies from cell lines and patient samples have suggested that this polymorphism leads to several changes, from mRNA level, protein expression and protein folding, to substrate specificity (Fung and Gottlesman, 2009).

In this study, C3435T and C1236T MDRl polymorphisms were not significantly associated with the development of ALL in Thai children. This observation supports previous reports of childhood ALL in Hispanic (Urayama et al., 2007), Mexican (Leal-Uqarte et al., 2007), Hungarian (Semsi et al., 2008), Chinese (Zhai et al., 2012) and Latvia population (Kreile M et al., 2014). On the other hand, many lines of evidence from Poland (Jamroziak et al., 2004), Japan (Hatori et al., 2007), India (Rao et al., 2010), and Turkey (Bekas-kayan et al., 2012), indicate that these genotypes are involved in the risk of childhood ALL. This genetic variation between different populations of ALL patients may be due to ethnic group differences, sample size, and heterogeneity of ALL patients. Likewise, ALL childhood patients were classified by risk-based assignment protocol into standard and high-risk groups (Smith et al., 1996). This study indicates that both $\mathrm{C} 3435 \mathrm{~T}$ and C1236T MDRl genotypes are significantly associated with high-risk groups for childhood ALL. Moreover, in five relapse cases of ALL were associated with polymorphism of MDRI C3435T and C1236T polymorphisms. However, it will be necessary to replicate these finding in large sample size.

In conclusion, MDR $1 \mathrm{C} 3435 \mathrm{~T}$ and $\mathrm{C} 1236 \mathrm{~T}$ polymorphisms are significantly associated with high risk ALL patients, and may be used as potential biomarkers for the prediction of clinical outcomes in childhood ALL.

\section{Acknowledgements}

This study was supported by funding from the Research Institute of Rangsit University. We thank all students from the Faculty of Medical Technology, Rangsit University, for their laboratory assistance, and Mr. Glad Rotaru and Mr. Paul Adams, of the Faculty of Tropical Medicine, Mahidol University, for English language proofreading of this manuscript.

\section{References}

Ambudkar SV, Kimchi-Sarfaty C, Sauna ZE, Gottesman MM (2003). P-glycoprotein: from genomics to mechanism. Oncogene, 22, 7468-5.

Bekaş-Kayan K, Kucukhuseyin O, Karagoz G, et al (2012). Is the MDRI C3435T polymorphism responsible for oral mucositis in children with acute lymphoblastic leukemia. Asian Pac J Cancer Prev, 13, 15251-5.

Borst P, Elferink RO (2002). Mammalian ABC transporters in health and disease. Annu Rev Biochem, 71, 537-592.

Claus R. Bartram, André Schrauder, Rolf Köhler, Martin Schrappe (2012). Acute lymphoblastic leukemia in children: treatment planning via minimal residual disease assessment. Dtsch Arztebl Int, 109, 652-8

Dong HJ, Miao KR, Qiao C, et al (2011). Polymorphisms and haplotypes in multidrug resistance 1 gene are not associated 
with chronic lymphocytic leukemia in Chinese population. Leukemia Lymphoma, 52, 1003-9.

Fung KL, Gottesman MM (2009). A synonymous polymorphism in a common $M D R 1$ (ABCB1) haplotype shapes protein function. Biochim Biophys Acta, 1794, 860-71.

Hattori H, Suminoe A, Wada M, et al (2007). Regulatory polymorphisms of multidrug resistance 1 (MDR1) gene are associated with the development of childhood acute lymphoblastic leukemia. Leuk Res, 31, 1633-1640.

He T, Mo A, Zhang K, Liu L (2013). ABCB 1/MDR1 polymorphism and colorectal cancer risk: a meta-analysis of case-control studies. Colorectal Dis, 15, 12-18.

Hoffmeyer S, Burk O, von Richter O, et al (2000). Functional polymorphisms of the human multidrug resistance gene: multiple sequence variations and correlation of one allele with P-glycoprotein expression and activity in vivo. Proc Natl Acad Sci, 97, 3473-8.

Hitzl M, Drescher S, van der Kuip H, et al (2001). The C3435T mutation in the human $M D R 1$ gene is associated with altered efflux of the P-glycoprotein substrate rhodamine 123 from CD56+ natural killer cells. Pharmacogenetics, 11, 293-8.

Jamroziak K, Robak T (2004). Pharmacogenomics of MDR1/ $\mathrm{ABCB} 1$ gene: the influence on risk and clinical outcome of haematological malignancies. Hematology, 9, 91-105.

Jamroziak K, Mlynarski W, Balcerczak E, et al (2004). Functional C3435T polymorphism of MDRl gene: an impact on genetic susceptibility and clinical outcome of childhood acute lymphoblastic leukemia. Eur J Haematol, 72, 314-321.

Kerb R (2006). Implications of genetic polymorphisms in drug transporters for pharmacology. Cancer letters, 234, 4-33.

Kim RB., Leake BF., Choo EF, et al (2001). Identification of functionally variant $M D R 1$ alleles among European Americans and African Americans. Clin Pharmacol Ther, 70, 189-99.

Komar AA (2007). Silent SNPs: impact on gene function and phenotype. Pharmacogenomics, 8, 1075-80.

Kreile M, Rots D, Plekuse L, et al (2014). Lack of association between polymorphism in genes MTHFR and MDR1 with the risk of childhood acute lymphoblastic leulemia. Asian Pacific J Cancer Prev, 15, 9707-11

Kurzawski M, Droździk M, Suchy J, et al (2005). Polymorphism in the P-glycoprotein drug transporter $M D R 1$ gene in colon cancer patients. Euro J Clinical Pharmacology, 61, 389-94.

Lavedriere C, Chiasson S, Costea I, Moghrabi A, Krajinovic M (2002). Polymorphisms G80A in in the reduced folate carrier gene and its relationship to methotrexate plasma levels and outcome of childhood lymphoblastic leukaemia. Blood, 100, 3832-4.

Leal-Uqarte E, Gutiérrez-Angulo M, Macias_Gómez NM, et al (2008). MDRl C3435T polymorphism in Mexican children with acute lymphoblastic leukemia and in healthy individuals. Hum Biol, 80, 449-455.

Martin Belson, Beverely Kingsley, Adrianne Holmes (2007). Risk factors for acute leukemia in children: A review. Environmental Health Perspectives, 115, 141-5.

McLeod HL, Krynetski EY, Relling MV, Evans WE (2000). Genetic polymorphism of thiopurine methyltransferase and its clinical relevance for childhood acute lymphoblastic leukaemia. Leukemia, 14, 567-2.

Miler SA, Dykes DD, Polsky HF (1988). Simple salting out procedure for extracting DNA from human nucleated cells. Nucleic Acids Res, 16, 1215.

Nakamura T, Sakaeda T, Horinouchi M, et al (2002). Effect of the mutation (C3435T) at exon 26 of the MDRl gene on expression level of MDR1 messenger ribonucleic acid in duodenal enterocytes of healthy Japanese subjects. Clin Pharmacol Ther, 71, 297-303.
Ozdmir S, Uladag A, Silan F, et al (2013). Possible roles of xenobiotic transporter P-glycoproteins encoded by the MDR1 $3435 \mathrm{C}>\mathrm{T}$ gene polymorphism in differentiated thyroid cancer. Asian Pac J Cancer Prev, 14, 3213-7.

Pui CH, Relling MV, Downing JR (2004). Acute lymphoblastic leukemia. $N$ Engl J Med, 350, 1535-48.

Rao DN, Anuradha C, Visnupriya S, et al (2010). Association of an MDRl gene (C3435T) polymorphism with acute leukemia in India. Asian Pac J Cancer Prev, 11, 1063-6.

Ren YQ, Han JQ, Cao JB, LiSX, Fan GR (2012). Association of MDRl gene polymorphisms with susceptibility to hepatocellular carcinoma in Chinese population. Asian Pac J Cancer Prev, 13, 5451-4.

Ryu HC, Kwon HY, Choi IK, Rhee DK (2006). Analysis of single nucleotide polymorphisms and haplotype linkage of human ABCB1 (MDR1) gene in Korean. Arch Pharam Res, 29, 1132-9.

Sammanian S, Mahjoubi F, Mahjoubi B, Mirzaee R, Azizi R (2011). MDRl gene polymorphisms: possible association with its expression and clincopathology characteristics in colorectal cancer patients. Asian Pac J Cancer Prev, 12, 3141-5.

Semsei AF, Erdélyi DJ, Ungvári I, et al (2008). Association of some rare haplotypes and genotype combinations in the MDRl gene with childhood acute lymphoblastic leukemia. Leuk Res, 32, 1214-20.

Sheng X,Zhang L, Tong N (2012). MDRl C3435T polymorphism and cancer risk: a meta-analysis based on 39 case-control studies. Mol Biol Rep, 39, 7237-49.

Smith M, Arthur D, Camitta B, et al (1996). Uniform approach to risk classification and treatment assignment for children with acute lymphoblastic leukemia. J Clin Oncol, 14, 18-24.

Taheri M., Mahjoubi F., Omranipour R (2010). Effect of MDR1 polymorphism on multidrug resistance expression in breast cancer patients. Genet Mol Res, 12, 34-40.

Ullah MF (2008). Cancer multidrug resistance (MDR): A major impediment to effective chemotherapy. Asian Pac J Cancer Prev, 9, 1-6.

Urayama KY, Wiencke JK, Buffer PA, et al (2007). MDRl gene varients, indoor insecticide expourse, and the risk of childhood acute lymphoblastic leukemia. Cancer Epidemiol Biomarkers Prev, 16, 1172-7.

Wang J, Wang B, Bi J, Li K, Di J (2012). MDRl gene C3435T polymorphism and cancer risk: a meta-analysis of 34 casecontrol studies. Cancer Res Clin Oncol, 138, 979-89.

Wei HB, Hu J, Shang LH, et al (2012). A meta-analytic review of ERCC1/MDRl polymorphism and chemosensitivity to platinum in patients with advanced non-small cell lung cancer. Chin Med J, 125, 2902-7.

Wu DD, Zhang JX, Li J, Dong WG (2014). Lack of association of the MDR1 C3435T polymorphism with susceptibility to gastric cancer and peptic ulcer: A systematic review and meta-analysis. Asian Pac J Cancer Prev, 15, 3021-3027.

Yan PW, Huang XE, Yan F, Xu L, Jiang Y (2011). Influence of MDR1 gene codon 3435 polymorphisms on outcome of platinum based chemotherapy for advanced non small cell lung cancer. Asian Pac J Cancer Prev, 12, 2291-4.

Zhai X, Wang H, Zhu X, et al (2012). Gene polymorphisms of $\mathrm{ABC}$ transporters are associated with clinical outcomes in children with acute lymphoblastic leukemia. Arch Med Sci, $\mathbf{8}, 659-71$. 